\title{
Threatened fishes of the world: Seminemacheilus tongiorgii Nalbant and Bianco, 1998 (Balitoridae)
}

\author{
H. R. Esmaeili • A. Teimory • Brian W. Coad • \\ Z. Gholami
}

Received: 26 March 2008 / Accepted: 9 October 2008 / Published online: 12 November 2008

(C) Springer Science + Business Media B.V. 2008

Common name: Sagmahi-ye Hormuz (Farsi), Hormuz loach (E). Conservation status: None. Identification: Body short and deep with a row of small scales along the middle of the side of the body; lateral line short, not extending past the end of the pectoral fin. Lips furrowed, especially lower one. Processus dentiformis absent. Tail fin rounded. Body whitish-yellow with a row of gray blotches present on the dorsum and midside of the body, and a row of grey dots present on the posterior half of ventrum. Maximum length $5.7 \mathrm{~cm}$ SL. Distribution: The type locality is large freshwater spring near Darab in the Kul River basin, Fars Province, Iran but an extensive survey found no specimens there as water bodies had dried out. Now known only from Ghadamgah spring-stream system of the Kor River basin in Fars $\left(30^{\circ} 15^{\prime} 23.0^{\prime} \mathrm{N}, 5^{\circ} 25^{\prime} 36.42^{\prime} \mathrm{E}\right)$. Individual abundance low. Habitat and ecology: Ghadamgah is a natural spring-stream system leading to a few

H. R. Esmaeili • A. Teimory • Z. Gholami Department of Biology, Shiraz University,

Shiraz, Iran

B. W. Coad $(\bowtie)$

Canadian Museum of Nature,

P.O. Box, 3443, Station D,

Ottawa, Ontario K1P 6P4, Canada

e-mail: bcoad@mus-nature.ca

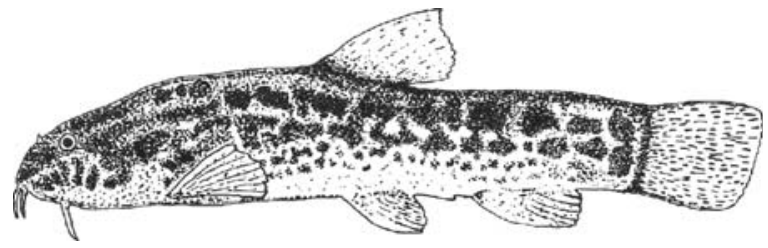

irrigation canals. The bottom is generally muddy or has small gravel. The water is almost clear and supports abundant aquatic plant growth. The species is sympatric with eight native species: Petroleuciscus persidis, Cobitis linea, Aphanius sophiae, Barbatula farsica, Capoeta damascina, Capoeta aculeata, Chondrostoma regium and Alburnus mossulensis, of which the first four are endemic to Iran. Reproduction: Unknown. Threats: Water diversion severely reduces water level, especially by pump wells; drainage rehabilitation which changes the whole structure of the system; water pollution from domestic and agricultural sources; recent droughts; and the development of an intensive local aquaculture industry with seven species of exotic that may colonise the spring. Conservation actions: None taken. Conservation recommendations: Some form of legal protection should be instituted, education of local people initiated, captive breeding undertaken, the biology of the species studied, and the habitat monitored. 